\title{
Effect of thermal treatment on physicochemical, phytochemical, and microbiological characteristics of brown Spanish onion paste
}

\author{
S. Naqash ${ }^{1}$, H. R. Naik ${ }^{2 *}$, S. Z. Hussain ${ }^{1}$, H. A. Makroo ${ }^{2 *}$ and B. N. Dar ${ }^{2 *}$ \\ ${ }^{1}$ Division of Food Science and Technology, Sher-E-Kashmir University of Agricultural Sciences and Technology of Kashmir, \\ Shalimar, Srinagar, Jammu and Kashmir, India; ${ }^{2}$ Department of Food Technology, Islamic University of Science and \\ Technology, Awantipora, Jammu and Kashmir, India
}

"Corresponding authors: H. R. Naik, Dean of Research, Islamic University of Science and Technology, Awantipora, Jammu and Kashmir, 192122, India. Email: haroon.naik@islamicuniversity.edu.in. H. A. Makroo, Assistant Professor, Department of Food Technology, Islamic University of Science and Technology, Awantipora, Jammu and Kashmir, 192122, India. Email: hilalmakroo@gmail.com; hilal.makroo@islamicuniversity.edu.in. B. N. Dar, Assistant Professor, Department of Food Technology, Islamic University of Science and Technology, Awantipora, Jammu and Kashmir, 192122, India. Email: darnabi@gmail.com

Received: 31 August 2021; Accepted: 16 October 2021; Published: 11 November 2021

(c) 2021 Codon Publications

\section{OPEN ACCESS (C) (1) O(2) ORIGINAL RESEARCH}

\begin{abstract}
Onion paste is a commercially used processed product that reduces cooking time. Industrial processing of onion paste involves various treatments that affect the overall nutritional profile of the final product. In this study, effect of various thermal treatment conditions was evaluated, with temperature and time ranging between 70 and $90^{\circ} \mathrm{C}$ for 8 to $22 \mathrm{~min}$, respectively. Changes in quercetin, pyruvic acid, and quality characteristics of fresh onion paste were investigated. A negative linear trend was observed in quercetin, pyruvic acid, viscosity, ascorbic acid, and total plate count, with an increase in temperature and time. An interactive and combined effect of time and temperature showed a positive linear relationship with color difference. For all the quality parameters investigated in this study, thermal treatment at $87^{\circ} \mathrm{C}$ for $15 \mathrm{~min}$ was found to be optimum for development of shelf-stable onion

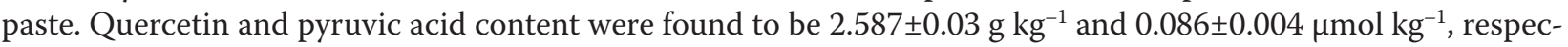
tively. Optimum conditions depicted better retention of principal compounds as compared to the other experimental conditions and exhibited safer quality product as compared to the untreated sample.

Industrial relevance: Brown Spanish onion is a perishable produce due to high moisture content. In order to reduce its postharvest losses at domestic and commercial levels, optimized processing parameters for the production of onion paste can be economically beneficial, and it is a highly acclaimed product for consumer usage.
\end{abstract}

Keywords: microbiological stability; pyruvic acid; quercetin; shelf-life; thermal treatment

\section{Introduction}

Onion (A.cepa, L.) is an extensively consumed bulb crop across the globe standing second to tomato (Nicastro et al., 2015), and its consumption in any form has been associated with its diverse health benefits. The versatile nature of onion and its products is ascribed to various bioactive compounds that include phenolic compounds, flavonoids, thiosulfinates, and other antioxidants (Lee et al., 2015). Various researches have concluded that continuous consumption of onions can alleviate cardiovascular ailments, respiratory diseases besides taking care of several cancers (Fredotović and Puizina, 2019). Across the globe, different types of onions are cultivated that include red, white, and yellow onions, categorized according to their outer skin color. In general, onions 
are considered to be rich in flavonols, majorly containing quercetin, thereby recognized as its most important dietary source (Siddiq et al., 2013). Several studies have revealed the chemical composition of onions disclosing their appealing nutritional and therapeutic properties. Dini et al. (2008) reported that onions form a good source of vitamins, proteins, carbohydrates, dietary fibers, and phenolic compounds. In addition, onions also display antimicrobial, anti-carcinogenic, and hypoglycemic properties (Tattelman, 2005). Pungency in onions is due to the presence of several volatile sulfur compounds that are produced during mechanical disruption of onion cells by the action of enzyme allinase, and its activity is correlated with perceived pungency in onions (Caruso et al., 2014). However, in recent studies, it has been observed that onion cultivars with low pungency have an increased demand and recognition in both uncooked and fresh form. Brown Spanish variety of onions is an introduced variety in Kashmir and is majorly cultivated across the valley. These onions have a papery dark yellow to golden brown color, and are milder in taste (Efiong et al., 2020), making them useful for frying and also as flavor enhancers in stews and soups.

As reported by FAO (2004), the global production of onions was estimated to be 5 million MT with China as the top contributor, producing $28 \%$ of the world production followed by India, producing $18 \%$ of the global production. Although Onions are produced in large quantities all over the world, huge post-harvest loss occurs, majorly due to surplus produce, inconsistent climatic conditions, and improper post-harvest management. In regions with high temperature and high relative humidity, losses are as huge as $40 \%$ of the total annual produce (Fredotović and Puizina, 2019). Increased perishability of onions is majorly due to their high moisture, ranging between 75 and 88\% (Dinkechaand Muniye, 2017). To decrease the losses and ensure their availability in glut seasons, processing into different forms like pastes, flakes, powders, and tablets are being highly considered. Onion paste is a commercially viable processed product that can ease out the usage of onions in everyday cuisines. Industrial processing of onion paste involves various treatments that effect the overall nutritional profile of the final product. To address this issue, traditional pasteurization is employed that targets the pertinent microbes of public health significance (Silva and Gibbs, 2010).

Viability of bio-compounds, their health benefits, and microbial stability in any processed product is directly dependent on processing techniques used. It is a common industrial practice to pasteurize the processed products in order to eliminate the chances of microbial spoilage during storage; however, limited literature is available on the stability and quality of onion pastes, in spite of being an important ingredient of almost all the cuisines across the globe and a fundamental source of dietary quercetin content. The objective of this study was to establish a relationship between thermal treatment conditions and various quality parameters of onion paste from brown Spanish variety of onions that are highly acclaimed and potentially the cultivated variety in Kashmir valley. The optimized thermal treatment condition was also obtained while laying desired criteria for various quality responses.

Hypothesis: Thermal treatments will enhance the shelf life of the onion paste

\section{Materials and Methods}

\section{Plant material}

Brown Spanish onions, (Allium cepa, L.) were purchased from the local market at the time of harvest. The onions were cured artificially under optimum curing conditions and then used for paste preparation. All the chemicals used in the experiment were procured from Sigma Aldrich.

\section{Preparation of onion paste}

Onion paste was prepared by a method given by Ahmed and Shivhare (2001) with slight modifications. The cured onion bulbs were deskinned, cut, and instantly processed into paste using a laboratory size grinder. To obtain a paste of uniform consistency, it was allowed to pass through a 14-mesh sieve and was held at a temperature of $25 \pm 1^{\circ} \mathrm{C}$ for $1 \mathrm{~h}$ to smoothen the progress of flavor development and desirable enzymatic color change. The initial $\mathrm{pH}$ of the paste was $5.49 \pm 0.01$, which is quiet high and feasible for instant microbial growth. In order to adjust the $\mathrm{pH}$ to $4.1-4.3,30 \%(\mathrm{w} / \mathrm{v})$ citric acid solution was added and the paste was transferred to the glass vials, followed by heat treatment at different time and temperature combinations of the experimental design, as depicted in Table 1.

Statistical design and analysis of central composite rotatable design(CCRD) from design expert 12 (StatEase Inc, Minneapolis, MN-USA)was employed to estimate the effects of thermal treatment temperature "T," $70-90^{\circ} \mathrm{C}$ and time " $\mathrm{t}$ " 5-22 min on different properties of the onion paste. Coded and the actual levels of the experiment ranges for two independent variables were used and each variable was evaluated at five different levels coded as $-\alpha,-1$. 0.1 and $\alpha$, where, $\alpha$ equals to $2^{\mathrm{n} / 4}, \mathrm{n}$ representing the number of variables, indicating the minimum $(-)$ and maximum $(+)$ value of the variables; the values should be within this range. The 
Table 1. Effect of process parameters on different characteristics of onion paste changes in characteristics of onion paste at different time and temperature combinations.

\begin{tabular}{|c|c|c|c|c|c|c|c|}
\hline Run & $\begin{array}{c}\text { Temperature } \\
\left({ }^{\circ} \mathrm{C}\right)\end{array}$ & $\begin{array}{l}\text { Time } \\
(\mathrm{min})\end{array}$ & $\Delta \mathrm{E}$ & $\begin{array}{l}\text { Quercetin } \\
\left(\mathrm{g} \mathrm{kg}^{-1}\right)\end{array}$ & $\begin{array}{l}\text { Pyruvic acid } \\
\left(\mu \mathrm{mol} \mathrm{kg}{ }^{-1}\right)\end{array}$ & $\begin{array}{l}\text { Viscosity } \\
\text { (Pa-sec) }\end{array}$ & $\begin{array}{c}\text { TPC } \\
\log _{\left(\text {cfug }^{-1}\right)}\end{array}$ \\
\hline 1 & $1(87)$ & $-1(8)$ & 19.01 & 2.598 & 0.089 & 376 & 1.95 \\
\hline 2 & $0(80)$ & $0(15)$ & 16.36 & 2.625 & 0.044 & 362 & 1.99 \\
\hline 3 & $0(80)$ & $-1.41(5)$ & 16.58 & 2.693 & 0.078 & 392 & 2.06 \\
\hline 4 & $-1.41(70)$ & $0(15)$ & 13.59 & 2.692 & 0.039 & 449 & 2.07 \\
\hline 5 & $0(80)$ & $0(15)$ & 17.17 & 2.621 & 0.087 & 365 & 2.00 \\
\hline 6 & $0(80)$ & $0(15)$ & 16.77 & 2.640 & 0.034 & 363 & 1.99 \\
\hline 7 & $0(80)$ & $0(15)$ & 16.95 & 2.553 & 0.072 & 372 & 2.01 \\
\hline 8 & $0(80)$ & $1.41(25)$ & 17.07 & 2.574 & 0.049 & 369 & 1.98 \\
\hline 9 & $0(80)$ & $0(15)$ & 17.43 & 2.603 & 0.065 & 367 & 1.98 \\
\hline 10 & $-1(73)$ & $-1(8)$ & 15.12 & 2.703 & 0.059 & 439 & 2.07 \\
\hline 11 & $1.41(90)$ & $0(15)$ & 21.89 & 2.511 & 0.062 & 352 & 1.93 \\
\hline 12 & $-1(73)$ & $1(22)$ & 15.51 & 2.675 & 0.054 & 405 & 2.04 \\
\hline 13 & $1(87)$ & $1(22)$ & 19.83 & 2.573 & 0.059 & 360 & 1.95 \\
\hline
\end{tabular}

design required 13 experimental runs and consisted of factorial points(4), star corner points (4), and five center points. The experimental data were analyzed using the regression procedure of response surface methodology and the parameters obtained post-analysis were substituted in the second-order polynomial equation given below.

$$
y=b_{o}+\sum_{i=1}^{3} b_{i} x_{i}+\sum_{i=1}^{3} b_{i i} x_{i}^{2}+\sum_{i=1}^{3} \sum_{i=1}^{3} b_{i j} x_{i} x_{j}
$$

where " $y$ " is the predicted response for each of the dependent variables, $x_{i}(i=1,2$, and 3$), x_{i}^{2}$, and $x_{i} x_{j}$ are linear, quadratic, and interaction effects of independent variables that have a significant effect on the response $y$ and $b_{o}, b_{i}$ and $b_{i j}$ represent the coefficients of regression for intercept, linear quadratic, and interaction effects, respectively.

The significance of the independent variables was tested by employing the analysis of variance (ANOVA), while the data analysis was done using paired $t$-test to depict the considerable effect of independent variables on the responses. Validation of the models was done as a function of their goodness of fit (actual $R^{2}$ ), goodness of prediction (predicted $\mathrm{R}^{2}$ ), and the analysis of lack of fit of the models.

\section{Statistical analysis}

For each experiment, data was recorded in triplicates and results were presented as mean $\pm \mathrm{SD}$. Statistical analysis of data was conducted using Microsoft Excel (MSOffice 2010), employing student's $t$-test, at a significance level of 5\%.

\section{Process optimization and validation}

Optimization of the thermal treatment process was done using a desirability function approach. To acquire the most favorable values for the responses, the required goals were assigned to all the responses as per the desirability. Color of any food product is an important parameter, therefore the change in color $(\Delta \mathrm{E})$ with respect to the thermal treatment was minimized; however, quercetin content and pyruvic acid content was supposed to be maximum. The viscosity of the paste was kept in range, as it did not show any constant trend with respect to the thermal treatment. Total plate count was minimized, considering the overall acceptability and stability of the product. Taking the preset conditions into account, response surface methodology software produced various optimal solutions, and a solution with the maximum desirability was selected for further studies of the developed onion paste.

For validation of the developed models, predicted and the actual results were compared. The selected optimum conditions were used for treating the onion paste that was further analyzed for the chosen responses. The percentage prediction error was calculated using equation (2) (Scheuer et al., 2016).

$\underset{\text { Predicted }}{\text { error }(\%)}=\frac{\text { Actual values }- \text { predicted values }}{\text { predicted values }} \times 100$

\section{Determination of product attributes}

\section{Physicochemical characteristics}

Proximate composition of onion paste, i.e., moisture content, protein, ash, fat, and crude fiber was estimated 
according to the procedures given by the Association of Official Analytical Chemists (AOAC, 2019). Total carbohydrate was estimated by the difference method. Water activity was estimated using a water activity analyzer (Lab touch $a_{w}$ meter, Novasina, Switzerland). Energy value was determined by using Atwater conversion factors, i.e., $4 \mathrm{kcal} / \mathrm{g}, 4 \mathrm{kcal} / \mathrm{g}$, and $9 \mathrm{kcal} / \mathrm{g}$ for carbohydrates, proteins, and fats, respectively. Dietary fiber was estimated using a dietary fiber system (Fibraplus DF- Mexico) following the AOAC (2019) procedure. Total soluble solids were estimated using a hand refractometer (Erma RHB32ATC, Tokyo), while $\mathrm{pH}$ values were estimated using a pH-meter with a glass electrode (Inolab. WTW Series, Germany). Titratable acidity was estimated by titrating the diluted paste against $0.1 \mathrm{~N} \mathrm{NaOH}$ solution with phenolphthalein as an indicator (Ranganna, 1997).

Total sugars were estimated by Lane and Eynon method as described by Ranganna (1997). Briefly, $50 \mathrm{~mL}$ of clarified solution was taken out using a pipette into a $250 \mathrm{~mL}$ conical flask to which $5 \mathrm{~g}$ of citric acid was added followed by the addition of $50 \mathrm{~mL}$ distilled water. The mix was boiled gently for $10 \mathrm{~min}$ to allow a complete inversion of sucrose and then allowed to cool down to room temperature, and was then neutralized with $1 \mathrm{~N} \mathrm{NaOH}$ using phenolphthalein as an indicator, and the volume was made up to $250 \mathrm{~mL}$. The amount of total and reducing sugars was calculated using the below-given equations.

$$
\begin{aligned}
& \text { Reducing sugars }(\%) \\
& =\frac{\text { mg of invert sugar } \times \text { dilution } \times 100}{\text { Titer value } \times \text { weight of sample } \times 100}
\end{aligned}
$$

\%total sugars as invert sugars

$$
\begin{gathered}
=\frac{\text { mg of invert sugars } \times \text { dilution } \times 100}{\text { Titer value }(\text { after inversion }) \times \text { wt of sample } \times 100} \\
\% \text { sucrose }=(\% \text { total invert sugar } \\
\quad \% \text { reducing sugars originaly present }) 0.95 \\
\% \text { total Sugars }=\% \text { reducing sugars }+\% \text { sucrose }
\end{gathered}
$$

\section{Tannic acid}

Tannic acid was estimated using the method given by AOAC (2019), with slight modifications. A $0.5 \mathrm{~g}$ sample was taken in a $250 \mathrm{~mL}$ conical flask, to which $75 \mathrm{~mL}$ double distilled water was added. The flask was heated gently and allowed to boil for $30 \mathrm{~min}$., followed by centrifugation at $2000 \mathrm{rpm}$ for $20 \mathrm{~min}$. The supernatant was collected in a $100-\mathrm{mL}$ flask containing $75 \mathrm{~mL}$ water, followed by the addition of $5 \mathrm{~mL}$ Follin Dennis reagent and $10 \mathrm{~mL}$ sodium carbonate. The mix was diluted to $100 \mathrm{~mL}$ with double distilled water and allowed to rest for $30 \mathrm{~min}$, before the measurement of absorbance at a wavelength of 700nm using UV-Vis 300 spectrophotometer (Spectrum Instruments, Perkin Elmer company, U.K, SP-UV 300).
The amount of tannic acid was estimated as $\mathrm{mg} / 100 \mathrm{~g} \mathrm{db}$, using a calibration curve prepared from standard tannic acid.

\section{Oleoresins}

Extraction was done by using the method given by Arjona et al. (2002) with slight modifications. Ten grams of onion paste was mixed with $20 \mathrm{mLhexane}$. The mixture was kept in a shaking incubator for $20 \mathrm{~h}$ at $25^{\circ} \mathrm{C}$, followed by filtration through Whatman No.1 filter paper. The remaining solvent was removed using a rotary evaporator (IKA-HB 10 rotavapor, India) at $40^{\circ} \mathrm{C}$ as mentioned by Duarte et al. (2004). The oleoresins' yield was calculated using equation (7).

$$
\text { Oleoresins }(\%)=\frac{\mathrm{W}_{2}-\mathrm{W}_{1}}{\mathrm{~W}_{2}} \times 100
$$

where, $\mathrm{W}_{2}=$ weight of flask + Oleoresin; $\mathrm{W}_{1}=$ weight of empty flask

\section{Ascorbic acid}

Ascorbic acid was estimated using AOAC (2019) procedure. Approximately, 5gsample was taken in a conical flask and 3\% metaphoric acid was added to make up the volume to $100 \mathrm{~mL}$. Ten $\mathrm{mL}$ aliquot was pipetted out in a titration flask and titrated against 2, 6-dichlorophenol indophenols till the appearance of light pink color. Ascorbic acid was then calculated using equation (8)

$$
\begin{aligned}
& \text { Ascorbic acid }\left(\frac{\mathrm{mg}}{100 \mathrm{~g}}\right) \\
& =\frac{\text { titer value } \times \text { dye factor } \times \text { volume made up } \times 100}{\mathrm{~mL} \text { of filtrate taken } \times \text { weight of sample taken for estmation }}
\end{aligned}
$$

Dye factor was estimated by the titration of $5 \mathrm{~mL}$ standard ascorbic acid added to $5 \mathrm{~mL} 3 \%$ metaphosphoric acid against 2, 6-dichlorophenol indophenols. The appearance of light pink color was taken as the endpoint and the volume appeared and volume used (titer value) were noted.

$$
\text { Dye Factor }=\frac{0.5}{\text { Titre value }}
$$

\section{Quercetin content}

Quercetin in onion paste was estimated using UV-Vis Spectrophotometer (SP-UV 300, Spectrum Instruments, Perkin Elmer company, U.K), by employing the method given by Pejic et al. (2004), with slight changes. Approximately, $5 \mathrm{~g}$ of onion paste was taken in a conical flask, to which $80 \mathrm{~mL}$ of $80 \%$ ethanol was added. The mixture was stirred for $10 \mathrm{~min}$ at $700 \mathrm{rpm}$ and then filtered through a Whatman No. 42, and the filtrate was collected in centrifuge tubes. One milliliter of the filter was taken out using a pipette and diluted 
with $80 \%$ ethanol in a ratio of $1: 10$ to a total of $5 \mathrm{~mL}$. Absorbance was observed at $362 \mathrm{~nm}$ using a UV-Vis Spectrophotometer (SP-UV 300, Spectrum Instruments, Perkin Elmer company, U.K). A standard calibration curve was prepared using the standard quercet in that was further used to estimate the total amount of quercetin as $\mathrm{mg} \mathrm{kg}^{-1}$ dry weight.

\section{Pyruvic acid}

Pyruvic acid was estimated by using a method given by Liguori et al. (2017). Clarified onion juice was obtained from the paste by pressing it through a muslin cloth and then filtering using Whatman filter paper. Ten microliters of juice was taken out using a micropipette and added to $0.5 \mathrm{~mL}$ of $0.125 \mathrm{~g} \mathrm{~L}^{-1} \mathrm{DNPH}$ in $2 \mathrm{M} \mathrm{HCl}$ for the reactions to take place. The samples were heated in a water bath at $37 \pm 1^{\circ} \mathrm{C}$ for $10 \mathrm{~min}$, followed by the addition of $2.5 \mathrm{~mL}$ of $0.6 \mathrm{M}$ sodium hydroxide solution. A standard calibration curve was prepared using sodium pyruvate as a standard, and pyruvic acid solutions were prepared in water at concentrations of $0.04-0.4 \mathrm{mmol} \mathrm{L}^{-1}$. Absorbance was measured at $420 \mathrm{~nm}$ using a UV-Vis spectrophotometer, and the amount of pyruvic acid was expressed as $\left(\mu \mathrm{mol} \mathrm{kg} \mathrm{kg}^{-1}\right)$ on dry basis.

\section{Color}

Color analysis was done using hunter lab equipment (Colour Flex EZ, Virginia) and expressed in a hunter system. The parameters were estimated as $L^{*}$ (Lightness), $a^{*}$ $(+\mathrm{a}=$ redness, $-\mathrm{a}=$ green $)$, and $\mathrm{b}^{*}(+\mathrm{b}=$ yellow and $-\mathrm{b}=$ blue). The change in color $(\Delta \mathrm{E})$ due to thermal processing was estimated using equation (10)

$$
\Delta E=\sqrt{\left(L_{2}^{*}-L_{1}^{*}\right)^{2}+\left(a_{2}^{*}-a_{1}^{*}\right)^{2}+\left(b_{2}^{*}-b_{1}^{*}\right)^{2}}
$$

\section{Viscosity}

Viscosities of the thermally treated onion paste samples were estimated using a Rotational viscometer (Visco QCTM 100, Anton Paar, Austria) at room temperature $\left(25 \pm 2^{\circ} \mathrm{C}\right)$ as per the method given by Ahmed and Shivhare (2001). Onion paste was placed in a $50 \mathrm{~mL}$ flat-bottom beaker. Spindle RH-6 was used, and the equipment was set in auto mode.

\section{Microbiological analysis}

Microbial analysis of the processed paste was done for estimating standard total plate counts, yeast and mold counts, and coliforms according to the procedures given by AOAC (2019). Briefly, $10 \mathrm{~g}$ of paste was taken in a sterile test tube followed by the addition of sterile peptone water $(0.1 \%)$ (15 mL). After proper blending of the sample with peptone water, serial dilution of the sample was done followed by pour plating on agar media. The microbial colony growth was visualized after incubation and results were expressed as $\log \mathrm{cfu} / \mathrm{g}$.

\section{Results and Discussion}

\section{A fit of models}

Statistics for fit summary indicated linear regression models for all the selected responses. Analysis of variance data provided in Table 2 indicates that the regression models developed for all the responses were highly significant $(p<0.05)$. For the developed onion paste, $R^{2}$ ranged between 0.8779 and 0.9618 for different quality parameters, suggesting a good fit of all the models. Predicted and adjusted $\mathrm{R}^{2}$ were found to be in reasonable agreement with each other with a difference less than 0.2. The coefficient of variation (CV) ranged between 1.16 and $4.33 \%$, depicting the reproducibility, precision, reliability, and reasonable accuracy of the results. A highly desirable adequate precision range between 11.65 and 24.43 was observed in all the models, suggesting the adequacy of model discrimination in all the parameters. Besides, lack of fit of non-significance was observed in all the parameters, implying a well correlated and desirable fitting of measured data with the developed models (Kazemi et al., 2015)

\section{Effect of process parameters on product characteristics}

\section{Quercetin}

Quercetin is one the most common and useful dietary flavonoids present in some fruits and vegetables with onion being an important source (Pękal et al., 2011). Quercet in possesses numerous health benefits and functions as an antioxidant, chelating agent, and a free radical scavenger (Sharifuldin et al., 2016). Quercetin in onion paste depicted a decreasing trend with an increase in processing temperature and time as shown in Table 1. Buchner et al. (2006) also reported a considerable decrease in quercetin over the processing time at $100^{\circ} \mathrm{C}$. Regression equation (11) for the changes in quercetin in onion paste during thermal processing is given in Table 2 .

Fit summary statistics suggested a linear model for quercetin in onion paste; therefore, only linear terms were generated in the regression equation (11). Both the linear terms ( $\mathrm{T}$ and $\mathrm{t}$ ) had negative effects on quercetin content. Table 2depicts that quercetin decreased considerably from $2.69 \mathrm{mg} \mathrm{kg}^{-1}$ to $2.51 \mathrm{mg} \mathrm{kg}^{-1}$, with an increase in temperature from 70 to $90^{\circ} \mathrm{C}$ and a change in time from 5 to $25 \mathrm{~min}$, establishing that the effect of temperature $(\mathrm{T})$ is greater than the effect of time $(\mathrm{t})$ on quercetin degradation, Figure 1A. A study by Chaaban et al. (2017) revealed that quercetin is highly vulnerable to an increase in pasteurization temperature and is degraded into various secondary metabolites, thereby decreasing its identifiable quantity. Thermal sensitivity of quercetin has been ascribed to the aglycone structure of quercetin. The 

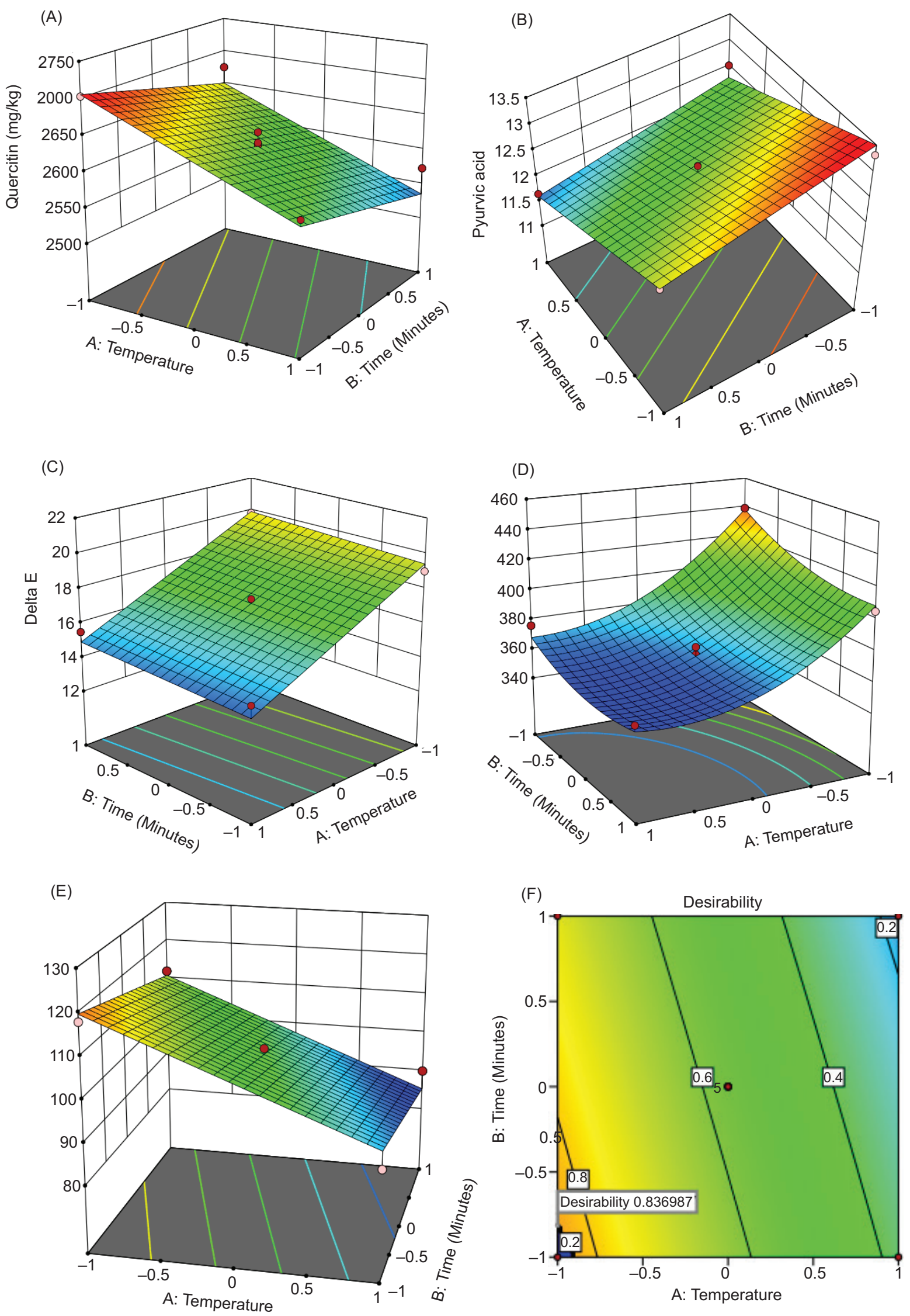

Figure 1. Effect of thremal processing time and temperature on (A) quercetin, (B) pyruvic acid,(C) $\Delta E,(D) v i s c o s i t y ~ P a-s$, (E) TPC Log cfu $\mathrm{mL}^{-1}$, and (F) desirablity graph. 
degradation products formed from quercetin depend on the type of heat treatment given as well as the conditions in which pasteurization is done. Similar results have been reported by Kumar et al.(2017) in grapefruit juice, where quercetin decreased due to pasteurization at $95^{\circ} \mathrm{C}$ for 80s. Unni and Chauhan (2018) also reported a decrease in flavonoid content of thermally treated onion paste as compared to then on thermally processed ones.

\section{Pyruvic acid}

Pyruvic acid is considered as a valid indicator of pungency in onions (Yoo and Pike, 2001). For different experimental runs, the pyruvic acid content of the onion pastes varied from $0.078 \mu \mathrm{mol} . \mathrm{kg}^{-1}$ to $0.089 \mu$ mol. $\mathrm{kg}^{-1}$ (Table 1 ). The fitted regression model developed for pyruvic acid content is given in equation (13)(Table 2).

The fitted regression model indicates a significant negative effect of heating time and temperature on pyruvic acid content of the onion paste, Figure 1B. Decreasein pyruvic acid due to increasing temperature is presumably due to the destruction of thiosulfates and other sulfur compounds during heating and mechanical processing. Similar results have been demonstrated by Cavagnaro et al. (2007), reporting major decline of sulfur compounds in onions due to heat treatment. Loss of pyruvic acid content might also be ascribed to cell structural damage in onions and the consequent losses of allinase at higher temperatures (Sharmaand Prasad, 2001).

\section{Color}

Color of any food product is influenced by physical, chemical, biochemical, and microbiological changes that occur during their post-harvest handling and processing (Pathare et al., 2013). Due to thermal treatment, lightness value of food products generally tends to decrease, resulting in an apparently darker product. The regression model fit for the color change in equation (12) is given in Table 2. The fit summary statistics suggested a linear model for color.

In equation (12), both the model terms $\mathrm{T}$ and $\mathrm{t}$ were significant, with $\mathrm{p}$-value $<0.001$, indicating a positive linear effect of time and temperature on color change. A considerable change was found in $L^{*}, a^{*}$, and $b^{*}$ values of onion paste with an increase in thermal processing temperature from 70 to $90^{\circ} \mathrm{C}$ and time from 5 to $25 \mathrm{~min}$. Decrease in $L^{*}$ and a* values was observed, while a corresponding increase was found in $b^{*}$ value. The total color change was estimated using different $L^{*}, a^{*}$, and $b^{*}$ values. It was found that there was a considerable increase in $\Delta \mathrm{E}$ from 13.59 to 21.89 with an increase in time and temperature, Figure 1C. Similar findings are reported by Ahmed and Shivhare (2001) in onion paste revealing first-order reaction kinetics of color degradation in it. The color change is supposedly attributed to Maillard

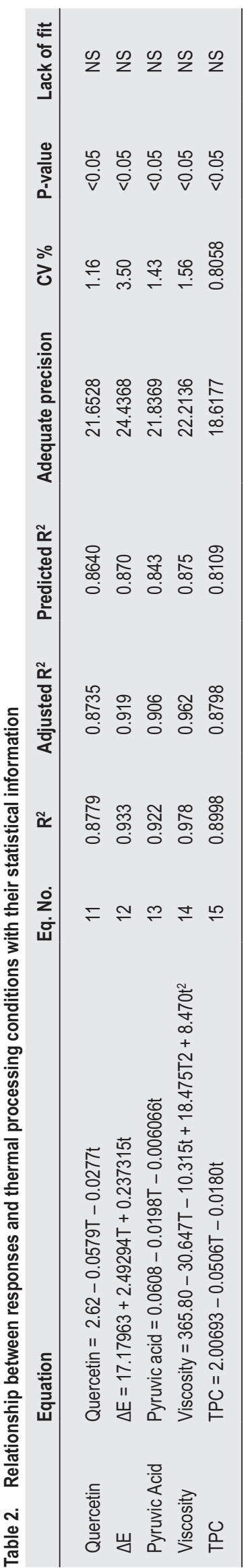


reactions that take place at high temperature as reported by Adam et al. (2000). Maillard reaction occurs due to the interaction of reducing sugars with amino acids in the presence of moisture and is accelerated at high temperatures during thermal processing (Jaeger et al., 2010). Similar results have been reported by Siddiq et al. (2013) while subjecting onions to a temperature treatment of 50 , 60 , and $70^{\circ} \mathrm{C}$.

\section{Viscosity}

Viscosity is an important parameter for texture of food products including food and condiment pastes. Regression equation for the viscosity of optimized onion paste is given in equation (14), Table 2, from which it is apparent that with an increase in time and temperature, there is a decrease in viscosity of the onion paste, Figure 1D. The decreasing trend of viscosity due to processing temperature can be attributed to change in the molecular orientation of the products due to increased temperature (Koochekietal., 2009). An increase in processing temperature results in a considerable increase in thermal energy of the food molecules due to thermal expansion, resulting in an increased intermolecular distance, thereby reducing the viscosity.

\section{Total plate count}

Microbial quality is an important parameter for consumer acceptability of food products (Chouhan et al., 2015). For different thermal time-temperature combinations, the total plate count of the onion pastes was found to vary between 1.95 and $2.07 \log \mathrm{cfu} \mathrm{g}^{-1}$, reducing from $2.90 \log \mathrm{cfu}^{-1}$ in fresh untreated samples. However, there was initial and final growth of yeast and molds and coliforms found in treated as well as untreated samples. The regression model for TPC is given in equation (15), Table 2, from which it is implied that there is a decrease in the total microbial plate count due to an increase in time and temperature of thermal treatment, Figure 1E. High temperatures tend to produce intense effects on the structural and physiological properties of almost all kinds of bacterial populations. Reduction in microbial load is due to the destruction of microbial cells throughout the thermal treatment. Similar observations have been reported by Balaswamy et al. (2004), where they have found a reduction of microbial load in onion chilli chutney treated at $87^{\circ} \mathrm{C}$. Besides the thermal treatment, $\mathrm{pH}$ of paste also plays an important role in preventing the growth of microbial pathogens. Cross contamination and contamination during treatments is ruled out because the processing was carried out under aseptic conditions, in UV-laminar flow chamber.

\section{Optimization of thermal treatment conditions}

The selected solution based on the highest desirability value (83\%), Figure $1 \mathrm{~F}$,of model acceptance suggested that thermal treatment at $87^{\circ} \mathrm{C}$ for 15 min was optimum to obtain an onion paste of good quality having less reduction in quercetin content, pyruvic acid content, color change, and optimum viscosity, and higher reduction in the total plate count. The predicted response values were reasonably close to the recorded values obtained after following optimized thermal treatment conditions. The values are depicted in Table 3.

\section{Comparison of treated and untreated sample}

\section{Physicochemical analysis}

The treated samples were found to be best as compared to the untreated onion paste. Physicochemical properties of the thermally treated optimized onion paste are depicted in Table 4. The proximate composition of the untreated and treated onion pastes did not have any significant difference; however, water activity $\left(\mathrm{a}_{\mathrm{w}}\right)$ of the treated sample was lesser than the untreated samples, which might be due to the evaporational loss of moisture in the thermally treated samples. There was no considerable change observed in $\mathrm{pH}$, titratable acidity, total soluble solids, and tannic acid of the treated onion paste.

\section{Pyruvic acid}

Pyruvic acid is considered as a prominent indicator for the quantification of organosulfur compounds (OSCs) in onions, produced by the enzymatic activation of S-Alkenyl-L-cysteine sulfoxides by allinase to generate pyruvic acid, ammonia, and sulfenic acids after the damage caused to the allium tissues (Perner et al., 2008). In our investigation, decrease in pyruvic acid by $2.3 \%$ was found. Gonzalez et al. (2010) reported a decline in pyruvic acid of thermally treated onion products presumably

Table 3. Predicted and actual responses.

\begin{tabular}{lccccc} 
Values & \multicolumn{3}{c}{ Responses } \\
\cline { 2 - 6 } & $\begin{array}{c}\text { Quercetin } \\
\left(\mathbf{g ~ k g}^{-1}\right)\end{array}$ & $\begin{array}{c}\text { Pyruvic acid } \\
\left(\mu \mathrm{mol} \mathrm{kg} \mathbf{~}^{-1}\right)\end{array}$ & $\Delta \mathrm{E}$ & $\begin{array}{c}\text { TPC } \\
\left(\text { Log cfu g }^{-1}\right)\end{array}$ & $\begin{array}{c}\text { Viscosity } \\
(\mathrm{Pa}-\mathrm{s})\end{array}$ \\
\hline Predicted & 2.687 & 0.085 & 15.874 & 2.059 & 396.11 \\
Actual & $2.713 \pm 0.05$ & $0.086 \pm 0.003$ & $15.902 \pm 0.13$ & $2.063 \pm 0.01$ & $398 \pm 1.5$ \\
Variation (\%) & 0.96 & 1.1 & 0.17 & 0.19 & 0.4 \\
\hline
\end{tabular}


Table 4. Effect of thermal processing on the quality of onion paste.

\begin{tabular}{|c|c|c|}
\hline Parameters (dry basis) & Fresh & $\begin{array}{l}\text { Thermally } \\
\text { Treated }\end{array}$ \\
\hline \multicolumn{3}{|l|}{ Proximate composition (\%) } \\
\hline Moisture content & $568.44 \pm 0.13^{a}$ & $568.51 \pm 0.27^{b}$ \\
\hline Crude protein & $12.53 \pm 0.03^{\mathrm{a}}$ & $12.52 \pm 0.03^{b}$ \\
\hline Crude fat & $7.10 \pm 0.01^{\mathrm{a}}$ & $7.11 \pm 0.01^{b}$ \\
\hline Crude fiber & $13.14 \pm 0.02^{\mathrm{a}}$ & $13.13 \pm 0.02^{b}$ \\
\hline Ash & $2.00 \pm 0.05^{a}$ & $2.06 \pm 0.06^{b}$ \\
\hline Carbohydrate & $67.56 \pm 0.03^{a}$ & $67.51 \pm 0.05^{b}$ \\
\hline \multicolumn{3}{|l|}{ Physicochemical properties } \\
\hline Water activity & $0.939 \pm 0.005^{a}$ & $0.937 \pm 0.01^{b}$ \\
\hline TSS (\%) & $13.00 \pm 0.05^{\mathrm{a}}$ & $12.00 \pm 0.05^{b}$ \\
\hline Titratable acidity (\%) & $0.232 \pm 0.005^{\mathrm{a}}$ & $0.233 \pm 0.09^{b}$ \\
\hline $\mathrm{pH}$ & $5.49 \pm 0.09^{b}$ & $4.12 \pm 0.08^{\mathrm{a}}$ \\
\hline Viscosity Pa-s & $496 \pm 1.52^{\mathrm{a}}$ & $398.03 \pm 2.77^{b}$ \\
\hline $\begin{array}{l}\text { Total quercetin content } \\
\left(\mathrm{g} \mathrm{kg}^{-1}\right)\end{array}$ & $3.05 \pm 0.08^{a}$ & $2.56 \pm 0.03^{b}$ \\
\hline Tannic acid $\left(\mathrm{g} \mathrm{kg}^{-1}\right)$ & $97.86 \pm 0.5^{\mathrm{a}}$ & $97.80 \pm 0.16^{b}$ \\
\hline Pyruvic acid $\left(\mu \mathrm{mol} \mathrm{kg}^{-1}\right)$ & $0.095 \pm 0.002^{\mathrm{a}}$ & $0.086 \pm 0.004^{b}$ \\
\hline Ascorbic acid $\left(\mathrm{g} \mathrm{kg}^{-1}\right)$ & $48.70 \pm 0.05^{a}$ & $41.40 \pm 0.16^{b}$ \\
\hline $\begin{array}{l}\text { Oleoresins }(\%) \\
\Delta \mathrm{E}\end{array}$ & $\begin{array}{c}4.36 \pm 0.09^{\mathrm{a}} \\
13.334 \pm 0.02^{\mathrm{a}}\end{array}$ & $\begin{array}{c}4.35 \pm 0.06^{b} \\
15.092 \pm 0.13^{b}\end{array}$ \\
\hline Energy (kcal/100g) & $384.26 \pm 0.05^{\mathrm{a}}$ & $384.24 \pm 0.05^{b}$ \\
\hline \multicolumn{3}{|l|}{ Sugar components } \\
\hline Total sugars $\left(\mathrm{g} \mathrm{kg}^{-1}\right)$ & $442.34 \pm 0.62^{\mathrm{a}}$ & $412.03 \pm 0.50^{b}$ \\
\hline Reducing sugars $\left(\mathrm{g} \mathrm{kg}^{-1}\right)$ & $239 \pm 0.27^{a}$ & $221.32 \pm 0.20^{b}$ \\
\hline Nonreducing sugars $\left(\mathrm{g} \mathrm{kg}^{-1}\right)$ & $202.94 \pm 0.14^{a}$ & $195.43 \pm 0.60^{b}$ \\
\hline \multicolumn{3}{|l|}{ Microbiological parameters } \\
\hline Total plate count (log cfu.g-1) & $3.079 \pm 0.02^{\mathrm{a}}$ & $1.99 \pm 0.08^{b}$ \\
\hline
\end{tabular}

due to inactivation of allinase. They demonstrated pyruvate as an indicator for the cell integrity retention while treating onion and its products at temperatures of 60,70 , and $90^{\circ} \mathrm{C}$, and established that there is an inactivation of allinase enzyme at these temperatures, leading to a decrease of pyruvic acid content in the processed product. The decreased quantity of pyruvate present in processed onion samples due to the inactivation of alliinase is also in agreement with the changes in organoleptic (pungency) quality reported by Butz et al. (1994) in highpressure-treated onions.

\section{Quercetin}

Quercetin is an important and predominant flavonoid present in onions existing in free and conjugated form as glucoside representing almost $80 \%$ of the total flavonol content of onions (Sharma et al., 2015). Results in our investigation showed a higher vulnerability of quercetin to thermal degradation almost up to $15 \%$ as the treatment temperature and time increased, as depicted in Table 1. Igual et al. (2011) reported a considerable reduction in flavonoids in grapefruit juice due to both conventional as well as microwave pasteurization, with no significant difference between the two processes. Aoyama et al. (2007) also reported the thermal instability of quercetin and its derivatives in onions at high temperatures ascribing to the structural destruction of flavonoids leading to a decreased estimation. As reported by Sharma et al. (2015), decrease in quercetin content can be attributed to the autolytic changes in the flavonoids during food processing. Wang et al. (2016) reported that factors like heat, $\mathrm{pH}$, metal ions affect the overall stability of quercetin during storage.

\section{Total sugars}

In our study, decrease of $6.8 \%$ in sugar was observed; however, the changes at different temperatures were minimal and did not differ significantly with changing temperatures. Similar results have been reported by Sharma et al. (2015), suggesting a minimal change in sugar content of onions till $100^{\circ} \mathrm{C}$ and the degradation of sugar has been reported to increase with the increase in temperature above $100^{\circ} \mathrm{C}$. A decrease in sugars may be due to the formation of Maillard reaction products resulting due to the chemical reaction between sugars amino acids and proteins (Martins et al., 2000). Redgwell et al. (2003) revealed that thermal treatment of foods like coffee/cocoa beans results in the destruction of glucose that can be ascribed to reactions between glucose and amino acids. These findings recommend that the onion by-products should be heated at a temperature below $120^{\circ} \mathrm{C}$ to maintain the required organoleptic characteristics.

\section{Viscosity}

Considerable difference in viscosities was found in onion pastes that were treated at different temperatures for different times. In our investigation, it was found that there was considerable decrease in the viscosity of the onion paste over the thermal treatment temperature and time. Decrease in viscosity at different temperatures and time can be attributed to an alteration of the molecular configuration of samples. Molecular fragmentation increases with an increase in shear rate that increases particleparticle interaction, resulting in a striking decline in viscosity. After a particular shear rate, viscosity becomes constant due to an unaltered molecular constitution of the particles that are present in the samples under consideration (Khushbu et al., 2020).

\section{Total plate count}

Preservation technologies are majorly based on microbial inactivation or the prevention and delay of microbial growth (Lee and Kang, 2004). In this study, the total plate count of onion paste ranged from $3.079 \pm 0.02$ to 
$1.99 \pm 0.03 \log \mathrm{cfug}^{-1}$, with the maximum being for the control sample. Our results are in concomitance with the results of Ahmed and Shivhare (2001) reporting a reduction of standard plate count of microbes in garlic paste from 4.22 to $2 \log$ cfu. ${ }^{-1}$ when treated at $95^{\circ} \mathrm{C}$ for $15 \mathrm{~min}$. Preservation techniques or factors tend to disturb one or more of the homeostasis mechanisms of the microbes, thereby preventing them from growing and multiplying or even rendering them dead (Sun, 2004).

\section{Conclusion}

The main aim of this study was to obtain the conditions that result in the production of a product with minimum loss of nutrients and higher shelf stability. From a nutritional point of view, it is imperative to minimize the losses during processing of onion pastes by controlling the treatment conditions. Therefore, to attain a representative onion product that offers superior quality characteristics, it was crucial to focus on optimization of the applied treatment. The optimal conditions that were obtained resulted in the retention of quercetin, pyruvic acid, and color $\left(0.086 \pm 0.004 \mu \mathrm{mol} \mathrm{kg} \mathrm{kg}^{-1}, 2.56 \pm 0.003 \mathrm{~g}\right.$ $\mathrm{Kg}^{-1}, 15.092 \pm 0.13$, respectively) at optimum levels, while the total plate count was reduced to the safe level of consumption of $1.99 \pm 0.08 \log \mathrm{CFU} \mathrm{g}^{-1}$. The optimum process parameters for the thermal treatment of onion pastes was found to be $87^{\circ} \mathrm{C}$ for $15 \mathrm{~min}$. Further research can be carried out to determine the shelf life of onion paste subjected to optimized thermal treatment conditions. There is scope for storage studies that can be carried out in order to validate the process for the production of a product with safe and longer shelf life. However, these conditions may not be generalized for other onion varieties that pave way for further extension of this research.

\section{List of units used}

$\begin{array}{ll}{ }^{\circ} \mathrm{C} & \text { Degree centigrade } \\ \mathrm{Min} & \text { Minutes } \\ \mathrm{g} \mathrm{kg}^{-1} & \text { Gram per kilogram } \\ \mu \mathrm{mol} \mathrm{kg} \mathrm{kg}^{-1} & \text { Micromole per kilogram } \\ \mathrm{Pa}-\mathrm{sec} & \text { Pascal second } \\ \mathrm{Log} \mathrm{cfug}{ }^{-1} & \text { Log of colony forming unit per gram } \\ \mathrm{mL} & \text { milliliter } \\ \% & \text { Percent } \\ \mathrm{G} & \text { Gram } \\ \mathrm{mg} \mathrm{100g} & \text { Milligram per } 100 \text { grams } \\ \mathrm{Rpm} & \text { Revolutions per minute }\end{array}$

\section{Conflict of Interest}

The authors declare no conflicts of interest.

\section{Funding}

No external funding was availed for this study

\section{Acknowledgement}

All the authors extended their gratitude to the Department of Food Technology, IUST Kashmir, and SKUAST-K, Srinagar, India, for providing the necessary facilities to conduct the present work.

\section{Ethical Guidelines}

Ethics approval was not required for this research.

\section{References}

Adam, E., Mühlbauer, W., Esper, A., Wolf, W. and Spiess, W., 2000. Quality changes of onion (Allium Cepa L.) as affected by the drying process. Food/Nahrung 44(1): 32-37. https:// doi.org/10.1002/(SICI)1521-3803(20000101)44:1\%3C32::AIDFOOD32\%3E3.0.CO;2-F

Ahmed, J. and Shivhare, U.S., 2001. Physico-chemical and storage characteristics of garlic paste. Journal of Food Processing and Preservation 25(1): 15-23. https://doi. org/10.1111/j.1745-4549.2001.tb00440.x

AOAC, 2019. Official methods of analysis. No. 630.24 A8 1984. Association of Official Analytical Chemists. Denver, Colorado, USA.

Aoyama, S. and Yamamoto, Y., 2007. Antioxidant activity and flavonoid content of Welsh onion (Allium fistulosum) and the effect of thermal treatment. Food Science and Technology Research 13(1): 67-72. https://doi.org/10.3136/fstr.13.67

Arjona, M., Amaya, S., Iriarte, A., García, V., Carabajal, D., \& Sosa, B. (2002). Effect of the drying system on the color and performance of oleoresin of paprika in the variety Capsicum annuum Elephant trunk. NOA Regional Congress of Science and Technology. Catamarca: National University of Catamarca

Balaswamy, K., Satyanarayana, A. and Rao, D.G., 2004. Studies on preparation and storage characteristics of onion (Allium Cepa L.)-chilly (Capsicum Annum) chutney. Foodservice Research International 15(3-4): 140-146. https://doi. org/10.1111/j.1745-4506.2005.00004.x

Buchner, N., Krumbein, A., Rohn, S. and Kroh, L.W., 2006. Effect of thermal processing on the flavonolsrutin and quercetin. Rapid Communications in Mass Spectrometry: An International Journal Devoted to the Rapid Dissemination of Up-to-theMinute Research in Mass Spectrometry 20(21): 3229-3235. https://doi.org/10.1002/rcm.2720

Butz, P., Koller, W.D., Tauscher, B. and Wolf, S., 1994. Ultra-high pressure processing of onions: chemical and sensory changes. LWT-Food Science and Technology 27(5): 463-467. https://doi. org/10.1006/fstl.1994.1093 
Caruso, G., Conti, S., Villari, G., Borrelli, C., Melchionna, G., Minutolo, M., Russo, G. and Amalfitano, C., 2014. Effects of transplanting time and plant density on yield, quality and antioxidant content of onion (Allium cepa L.) in southern Italy. Scientia Horticulturae 166: 111-120. https://doi.org/10.1016/j. scienta.2013.12.019

Cavagnaro, P. F., Camargo, A., Galmarini, C. R., \& Simon, P. W. (2007). Effect of cooking on garlic (Allium sativum L.) antiplatelet activity and thiosulfinates content. Journal of Agricultural and Food Chemistry 55(4): 1280-1288. https://doi.org/10.1021/ jf062587s

Chaaban, H., Ioannou, I., Chebil, L., Slimane, M., Gérardin, C., Paris, C., et al., 2017. Effect of heat processing on thermal stability and antioxidant activity of six flavonoids. Journal of Food Processing and Preservation 41(5): e13203. https://doi. org/10.1111/jfpp.13203

Chouhan, A., Pal Kaur, B. and Srinivasa Rao, P., 2015. Effect of high pressure processing and thermal treatment on quality of hilsa (Tenualosailisha) fillets during refrigerated storage. Innovative Food Science and Emerging Technologies 29: 151-160. https:// doi.org/10.1016/j.ifset.2015.03.016

Dini, I., Tenore, G.C. and Dini, A., 2008. Chemical composition, nutritional value and antioxidant properties of Allium caepa L. Var. tropeana (red onion) seeds. Food Chemistry 107(2): 613621. https://doi.org/10.1016/j.foodchem.2007.08.053

Dinkecha, K. and Muniye, M., 2017. Proximate composition and physicochemical properties of different released and improved onion (Allium cepa L.) bulbs varieties. Horticulture 67: 1-7

Duarte, C., Moldão-Martins, M., Gouveia, A.F., da Costa, S.B., Leitão, A.E. and Bernardo-Gil, M.G., 2004. Supercritical fluid extraction of red pepper (Capsicum frutescens L.). The Journal of Supercritical Fluids 30(2): 155-161. https://doi.org/10.1016/j. supflu.2003.07.001

Efiong, E.E., Akumba, L.P., Chukwu, E.C., Olusesan, A.I. and Obochi, G. 2020. Comparative qualitative phytochemical analysis of oil, juice and dry forms of garlic (Allium sativum) and different varieties of onions (Allium cepa) consumed in Makurdi metropolis. International Journal of Plant Physiology and Biochemistry 12(1): 9-16. https://doi.org/10.5897/IJPPB2019.0285

FAO, 2004. FAO production yearbook (Production de l'année). Food \& Agriculture Organization of the UN (FA Rome.

Fredotović, Ž. and Puizina, J., 2019. Edible allium species: chemical composition, biological activity and health effects. Italian Journal of Food Science 31(1): 19-39

Gonzalez, M.E., Anthon, G.E. and Barrett, D.M., 2010. Onion cells after high pressure and thermal processing: comparison of membrane integrity changes using different analytical methods and impact on tissue texture. Journal of Food Science 75(7): E426-E432. https://doi.org/10.1111/j.1750-3841.2010.01767.x

Igual, M., García-Martínez, E., Camacho, M.M. and MartínezNavarrete, N., 2011. Changes in flavonoid content of grapefruit juice caused by thermal treatment and storage. Innovative Food Science and Emerging Technologies 12(2): 153-162. https://doi. org/10.1016/j.ifset.2010.12.010

Jaeger, H., Janositz, A. and Knorr, D., 2010. The Maillard reaction and its control during food processing. The potential of emerging technologies. Pathologie Biologie 58(3): 207-213. https://doi.org/10.1016/j.patbio.2009.09.016

Kazemi, E., Shapiro, M., \& Kavner, A. (2015). Predictors of intention to turnover in behavior technicians working with individuals with autism spectrum disorder. Research in Autism Spectrum Disorders 17: 106-115. https://doi.org/10.1016/j. rasd.2015.06.012

Khushbu, S., Sunil, C.K., Chidanand, D.V. and Jaganmohan, R., 2020. Effect of particle size on compositional, structural, rheological, and thermal properties of shallot flour as a source of thickening agent. Journal of Food Process Engineering 43(3): e13237. https://doi.org/10.1111/jfpe.13237

Koocheki, A., Mortazavi, S.A., Shahidi, F., Razavi, S.M.A. and Taherian, R., 2009. Rheological properties of mucilage extracted from Alyssum homolocarpum seed as a new source of thickening agent. Journal of Food Engineering 91(3): 490-496. https:// doi.org/10.1016/j.jfoodeng.2008.09.028

Kumar, R., Vijayalakshmi, S. and Nadanasabapathi, S., 2017. Health benefits of quercetin. Defence Life Science Journal 2(2): 142151. https://doi.org/10.14429/dlsj.2.11359

Lee, S.-Y. and Kang, D.H., 2004. Microbial safety of pickled fruits and vegetables and hurdle technology. Internet Journal of Food Safety 4: 21-32.

Lee, E. J., Patil, B. S., \& Yoo, K. S. (2015). Antioxidants of 15 onions with white, yellow, and red colors and their relationship with pungency, anthocyanin, and quercetin. LWT-Food Science and Technology 63(1): 108-114. https://doi.org/10.1016/j. lwt.2015.03.028

Liguori, L., Califano, R., Albanese, D., Raimo, F., Crescitelli, A. and Di Matteo, M., 2017. Chemical composition and antioxidant properties of five white onion (Allium cepa L.) landraces. Journal of Food Quality 2017. https://doi.org/10.1155/2017/6873651

Ly, T.N., Hazama, C., Shimoyamada, M., Ando, H., Kato, K. and Yamauchi, R., 2005. Antioxidative compounds from the outer scales of onion. Journal of Agricultural and Food Chemistry 53(21): 8183-8189. https://doi.org/10.1021/jf051264d

Martins, S.I.F.S., Jongen, W.M.F. and Van Boekel, M.A.J.S., 2000. A review of Maillard reaction in food and implications to kinetic modelling. Trends in Food Science and Technology 11(9-10): 364-373. https://doi.org/10.1016/S0924-2244(01)00022-X

Nicastro, H.L., Ross, S.A. and Milner, J.A., 2015. Garlic and onions: their cancer prevention properties. Cancer Prevention Research 8(3): 181-189. https://doi.org/10.1158/1940-6207. CAPR-14-0172

Pathare, P.B., Opara, U.L. and Al-Julanda Al-Said, F., 2013. Colour measurement and analysis in fresh and processed foods: a review. Food and Bioprocess Technology 6(1): 36-60. https:// doi.org/10.1007/s11947-012-0867-9

Pejic, N., Kuntic, V., Vujic, Z. and Micic, S., 2004. Direct spectrophotometric determination of quercetin in the presence of ascorbic acid. Il Farmaco 59(1): 21-24. https://doi.org/10.1016/j. farmac.2003.07.013

Pękal, A., Biesaga, M. and Pyrzynska, K., 2011. Interaction of quercetin with copper ions: complexation, oxidation and reactivity towards radicals. Biometals 24(1): 41-49. https://doi. org/10.1007/s10534-010-9372-7 
Perner, H., Rohn, S., Driemel, G., Batt, N., Schwarz, D., Kroh, L.W. and George, E., 2008. Effect of nitrogen species supply and mycorrhizal colonization on organosulfur and phenolic compounds in onions. Journal of Agricultural and Food Chemistry 56(10): 3538-3545. https://doi.org/10.1021/jf073337u

Ranganna, S., 1997. Handbook of Analysis and Quality Control for Fruit and Vegetable Products, McGraw Hill Publication Co. Ltd., New Delhi.

Redgwell, R.J., Trovato, V. and Curti, D., 2003. Cocoa bean carbohydrates: roasting-induced changes and polymer interactions. Food Chemistry 80(4): 511-516. https://doi.org/10.1016/ S0308-8146(02)00320-5

Scheuer, P.M., Mattioni, B., Santos, I.R., Di Luccio, M., Zibetti, A.W., de Miranda, M.Z. and Francisco, A., 2016. Response surface methodology assessment of the effect of whole wheat flour and fat replacer levels on bread quality. International Food Research Journal 23(5): 2079-2087.

Sharifuldin, M.M.A., Ismail, Z., Aisha, A.F.A., Seow, E.K. and Beh, H.K. 2016. Quantification of rutin, quercitrin and quercetin in Cosmos caudatus Kunth by reverse phase high performance liquid chromatography. Quality Assurance and Safety of Crops and Foods 8(4): 617-622. https://doi.org/10.3920/ QAS2015.0839

Sharma, G.P. and Prasad, S., 2001. Drying of garlic (Allium sativum) cloves by microwave- hot air combination. Journal of Food Engineering 50(2): 99-105. https://doi.org/10.1016/ S0260-8774(00)00200-4

Sharma, K., Ko, E.Y., Assefa, A.D., Ha, S., Nile, S.H., Lee, E.T. and Park, S.W., 2015. Temperature-dependent studies on the total phenolics, flavonoids, antioxidant activities, and sugar content in six onion varieties. Journal of Food and Drug Analysis 23(2): 243-252.

Siddiq, M., Roidoung, S., Sogi, D.S. and Dolan, K.D., 2013. Total phenolics, antioxidant properties and quality of fresh-cut onions (Allium cepa L.) treated with mild-heat. Food Chemistry 136(2): 803. https://doi.org/10.1016/j.foodchem.2012.09.023

Silva, F.V.M. and Gibbs, P.A., 2010. Non-proteolytic Clostridium botulinum spores in low- acid cold-distributed foods and design of pasteurization processes. Trends in Food Science and Technology 21(2): 95-105, 806. https://doi.org/10.1016/j. tifs.2009.10.011

Sun J, Hobert ME, Rao AS, Neish AS, and Madara JL., (2004). Bacterial activation of beta-catenin signaling in human epithelia. Am J Physiol Gastrointest Liver Physiol 287: G220-G227. https://doi.org/10.1152/ajpgi.00498.2003

Tattelman, E., 2005. Health effects of garlic. American Family Physician 72(1): 103-106.

Unni, L.E. and Chauhan, O.P., 2018. Changes in quality attributes of onion paste during high pressure processing. International Journal of Food and Bioscience 1: 34-40.

Wang, W., Sun, C., Mao, L., Ma, P., Liu, F., Yang, J. and Gao, Y., 2016. The biological activities, chemical stability, metabolism and delivery systems of quercetin: a review. Trends in Food Science and Technology 56: 21-38. https://doi.org/10.1016/j. tifs.2016.07.004

Yoo, K.S. and Pike, L.M., 2001. Determination of background pyruvic acid concentrations in onions, Allium species, and other vegetables. Scientia Horticulturae 89(4): 249-256. https://doi. org/10.1016/S0304-4238(00)00196-5 